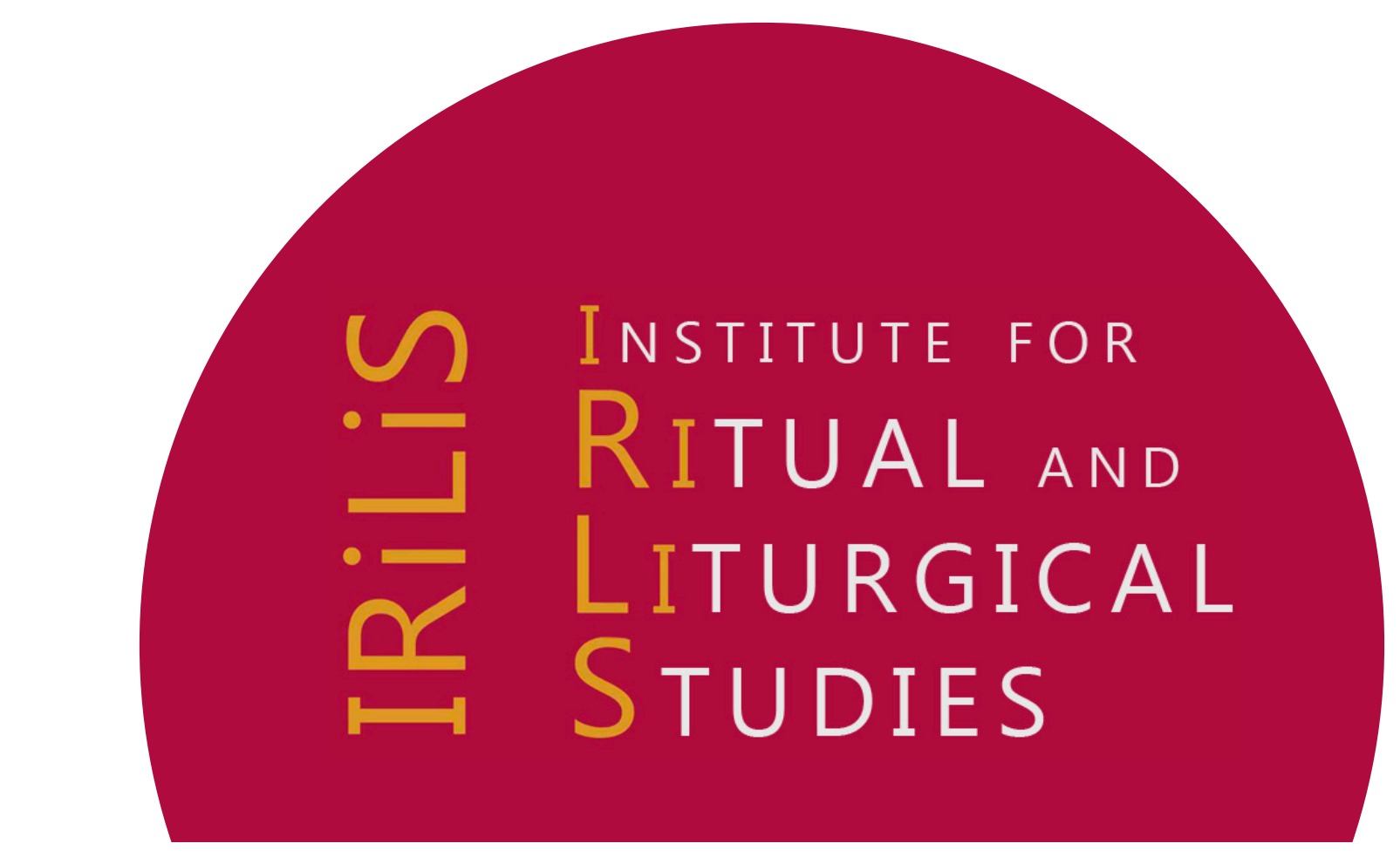

for Ritual and Liturgical Studies

Volume 33 | 2017

Institute for Ritual and Liturgical Studies, Amsterdam Centre for Religion and Heritage, Groningen 


\section{Yearbook for Ritual and Liturgical Studies}

The Yearbook for Ritual and Liturgical Studies is an online journal that annually offers a forum for innovative, national and international research in the field of ritual and liturgical studies.

\section{Editorial Board}

Prof. dr. Marcel Barnard (editor in chief, Amsterdam/Stellenbosch), dr. Andrew Irving (Groningen), dr. Martin Hoondert (Tilburg), dr. Mirella Klomp (Amsterdam), dr. Mary E. McGann (Berkeley, CA), prof. dr. Paul Post (Tilburg), prof. dr. Thomas Quartier (Nijmegen/Leuven/Rome), prof. dr. Gerard Rouwhorst (Utrecht/Tilburg), prof. dr. Eric Venbrux (Nijmegen).

\section{Advisory Board}

Prof. dr. Sible de Blaauw (Nijmegen), prof. dr. Joris Geldhof (Leuven), prof. dr. Bert Groen (Graz), prof. dr. Benedikt Kranemann (Erfurt), dr. Jan Luth (Groningen), prof. dr. Peter Jan Margry (Amsterdam), prof. dr. Keith Pecklers (Rome/ Boston), dr. Susan Roll (Ottawa), prof. dr. Martin Stringer (Swansea), prof. dr. Teresa Berger (New Haven, CT).

\section{Submitting articles}

You are kindly invited to submit a manuscript for publication in the online journal Yearbook for Ritual and Liturgical Studies by sending an email to irilis@pthu.nl.

\section{Length}

Articles should not normally exceed 8,000 words in length, including any notes, and should be submitted ready for publication. Illustrations (provided that they are free of rights) may separately be sent along. Summaries of dissertations (normally published in the language of the thesis) should not exceed 5,000 words. These should not contain any notes or illustrations.

\section{Language}

The Yearbook prefers receiving manuscripts written in English. You can also submit texts written in Afrikaans, Dutch, French or German. In case of an article written in a language other than the author's mother tongue, the text must be corrected at native speaker's level before submission. IRiLiS is not responsible for the quality of the correction, nor can cover its costs.

\section{Stylesheet}

When preparing your manuscript, please use the style sheet with editorial and bibliographical instructions.

\section{Deadline and anonymizing your manuscript}

The deadline for submissions is annually on May 1st. Manuscripts should be anonymized by the author prior to submission. If your submission is not anonymized, the editors will return it to you and request you to remove any identifying information.

\section{Peer review}

All submitted articles are subject to peer review. If a manuscript is not rejected when first received, it is sent out for review to (a minimum of) two peer reviewers who are part of the series' academic cadre of reviewers. Review by associate editors or staff may compliment this process. This is done according to a double-blinded review procedure, in which the reviewer's identities are withheld from the authors and vice versa. Once reviewers return their reports and recommendations, the editor-in-chief makes a decision (either on his own or in consultation with other editors) on whether to reject the manuscript (either outright or with encouragement to resubmit), to withhold judgment pending major or minor revisions, to accept it pending satisfactorily completed revisions, or to accept it as written. Once a manuscript that is not rejected has been revised satisfactorily, it will be accepted and put into the production process to be prepared for publication.
Editor Joyce Rondaij MA
ISSN 2589-3998
Design Yvonne Mathijsen
DOI 10.21827/5aze41ccedc3e 


\title{
Bidden als Vorm van Religieuze Coping bij Moslima's van Marokkaanse Afkomst
}

\author{
Leonie van der Valk, Jos Pieper \& Rien van Uden
}

\section{Abstract}

This article addresses the research question: "How do Islamic women of Moroccan descent use prayer in dealing with problems?" The theoretical framework was mainly based on the work of Pargament, Koenig \& Perez, regarding religious coping. ${ }^{1}$ The empirical part of the study consists of a quantitative and a qualitative part. This article presents the results of the quantitative part. For the quantitative part of our research 177 questionnaires were collected by use of snowball sampling. We questioned their praying practices and their ways of religious coping using the Brief RCOPE. The connection and communication with a loving, caring, benevolent God through prayer, is the main religious way these Islamic women of Moroccan descent cope with their problems. This use of prayer as a way of coping can be clarified by the psychological functions of religiosity and prayer that are suggested by Pargament et al. ${ }^{2}$ Prayer can help: (1) finding meaning, (2) being master over their circumstances and controlling their emotions, (3) finding comfort and closeness to God, (4) experiencing intimacy with others and closeness to God and (5) transforming their way of life. We did not find any negative religious coping strategies such as negative feelings towards God or alienation. This is in line with research results of Abu Raiya \& Pargament. ${ }^{3}$ As Islam implies surrender to God, it is difficult for Muslims to admit their religious distress, doubts and struggles.

\section{Keywords}

Islamic women, religious coping, prayer

1) Kenneth I. Pargament, Harold G. Koenig and Lisa M. Perez, "The Many Methods of Religious Coping: Development and Initial Validation of the RCOPE," Journal of Clinical Psychology 56, no. 4 (2000): 519-543.

2) Idem.

3) Hisham Abu Raiya and Kenneth I. Pargament, "Religious Integrated Psychotherapy with Muslim Clients: From Research to Practice." Professional Psychology: Research and Practice 41, no. 2(2010): 181-188. 


\section{Inleiding}

Centraal in dit artikel staat de vraag in hoeverre en hoe Nederlandse hoogopgeleide moslima's van Marokkaanse afkomst bidden gebruiken als vorm van religieuze coping. ${ }^{4}$ De beantwoording van deze vraag is gebaseerd op empirisch onderzoek dat is verricht naar de religieuze coping en het bidden van Nederlandse hoogopgeleide moslima's van Marokkaanse afkomst. Het ging daarbij om een kwantitatief alsook een kwalitatief onderzoek. In dit artikel beperken wij ons tot de resultaten van het kwantitatieve deel van dit onderzoek. De respondenten uit deze studie zijn de dochters en kleindochters van laaggeschoolde gastarbeiders die vanaf 1975 hun gezinnen naar Nederland lieten overkomen. Bij het kwantitatieve onderzoek is gebruik gemaakt van een vragenlijst die door 177 respondenten is ingevuld. De opbouw van dit artikel is als volgt: eerst wordt de theorievorming over religieuze coping en bidden behandeld, vervolgens worden de onderzoeksopzet en de onderzoeksresultaten uiteengezet en tot slot volgen de conclusie en discussie.

\section{Theorievorming over religieuze coping en bidden}

\subsection{Religieuze coping}

De godsdienstpsycholoog Pargament heeft onderzoek verricht naar de rol van religie bij het omgaan met spanningen en problemen. ${ }^{5}$ Veel mensen doen in tijden van nood een beroep op religieuze orientaties en voeren religieuze rituelen uit. Op momenten van crisis, pijn, verlies en verdriet geven religieuze oriëntaties en rituelen steun en kracht. Pargament is van mening dat veel mensen vooral religieuze coping gebruiken als gebeurtenissen zo ernstig en ingrijpend zijn dat er weinig alternatieve oplossingen beschikbaar zijn. Daarbij kan men zich volgens Pargament richten op het integreren van gebeurtenissen binnen een bestaand religieus referentiekader of zoeken naar nieuwe wegen van religiositeit en zingeving. Zo kan men vanuit religieuze motivatie besluiten om het eigen leven ingrijpend te veranderen en te streven naar innerlijke groei en transformatie. Ook kan men ondanks nare gebeurtenissen het eigen leven en dat van anderen als zinvol en waardevol ervaren. ${ }^{6}$ Dan is er sprake van positieve religieuze coping. Religieuze opvattingen en gedragingen kunnen echter ook stress veroorzaken of onzekerheden vergroten, bijvoorbeeld als men zich afvraagt of de crisis als een straf van God moet worden opgevat.

4) Dit artikel is gebaseerd op het promotieonderzoek van de eerste auteur L. van der Valk, Steun zoeken bij Allah. Religiositeit, bidden en religieuze coping van Nederlandse hoogopgeleide moslima's van Marokkaanse afkomst (Delft: Eburon, 2016).

5) Kenneth I. Pargament, The Psychology of Religion and Coping. Theory Research and Practice (New York: The Guilford Press, 1997).

6) Crystal L. Park and Jeanne M. Slattery, "Religion, Spirituality, and Mental Health," in Handbook of the Psychology of Religion and Spirituality, ed. R.F. Paloutzian and C.L. Park (New York: The Guilford Press, 2015), 540-560. 
Emmons \& Schnitker zijn van mening dat degenen die zich in hoge mate oriënteren op hun religie en die daar persoonlijk veel houvast, voldoening, zelfvertrouwen en doorzettingsvermogen door verkrijgen, beter met tegenslagen en leed kunnen omgaan.7 Zij beschikken immers over een oriëntatiesysteem om onverklaarbare en noodlottige omstandigheden te duiden. Vanuit hun religie kunnen zij verder richtlijnen volgen en handelingen verrichten waardoor zij minder ontregeld worden door tegenslag. Veel gelovigen bidden als zij het moeilijk hebben. Dit geeft hen troost en kracht. ${ }^{8}$ Wat is volgens onderzoekers kenmerkend aan bidgedrag en hoe werkt bidden bij het hanteren van stress?

\subsection{Bidden en coping}

Over bidden is veel geschreven en naar bidden is veel onderzoek verricht. ${ }^{9}$ De godsdienstpsychologen Janssen, De Hart \& Den Draak, en Prins, Baerveldt \& Van der Lans beschouwen bidden als een geïndividualiseerd ritueel, dat procesmatige en structurele kenmerken heeft. ${ }^{10}$ Vanwege dit procesmatige karakter van bidgedrag spreken Bänziger, Van Uden \& Janssen liever over 'bidden’ dan over 'het gebed'. ${ }^{11}$ Bidden als werkwoord geeft immers beter aan dat het om een dynamisch proces gaat. Het verschijnsel bidden kan verwijzen naar aanbidding, smeken, recitatie, conversatie, meditatie en contemplatie. Bidden kan plaatsvinden op vaste plaatsen of tijden of kan spontaan en impulsief zijn. Veel mensen bidden op een rituele manier, waarbij zij uitdrukking geven aan gevoelens en gedachten met behulp van bepaalde handelingen. Door middel van dit bidgedrag ontstaan ervaringen, die psychologische en lichamelijke effecten teweeg kunnen brengen. Psychologisch gezien is bidden dus een complexe vorm van gedrag waarbij er volgens Spilka \& Ladd sprake is van: "a broad spectrum of

\footnotetext{
7) Robert A. Emmons and Sarah A. Schnitker, "God and Goals. Religion and Purposeful Action," in Handbook of the Psychology of Religion and Spirituality, ed. R.F. Paloutzian and C.L. Park (New York: The Guilford Press, 2015), 25-274.
}

8) Compare: Pargament et al., "The Many Methods of Religious Coping”; Murray Levine, "Prayer as Coping: A Psychological Analysis," Journal of Health Care Chaplaincy 15, no.2 (2008): 80-98; Bernard Spilka and Kevin L. Ladd, The Psychology of Prayer. A Scientific Approach (New York: The Guilford Press, 2013).

9) Compare: M.M. Poloma and G.H. Gallup Jr., Varieties of Prayer: A Survey Report (Philadelphia: Trinity Press International, 1991); Richard J. Foster, Prayer: Finding the Heart's True Home (New York: Harper Collins, 1992); Laurence B. Brown, The Human Side of Prayer: The Psychology of Praying (Birmingham Alabama: Religious Education Press, 1994); Sarah Bänziger, Still Praying Strong. An Empirical Study of the Praying Practices in a Secular Society (Enschede, 2007).

10) Jacques Janssen, Joep de Hart and Christine den Draak, "A Content Analysis of the Praying Practices of Dutch Youth,” Journal for the Scientific Study of Religion 29, no.1 (1990): 99-107; Jacques Janssen, Maarten Prins, Cor Baerveldt en Jan van der Lans, "Structuren en varianten van bidden. Een onderzoek bij Nederlandse jongeren," in Wat baat religie? Godsdienstpsychologen en godsdienstsociologen over het nut van religie, ed. M. van Uden and J. Pieper (Nijmegen: KSGV, 1998), 67-97.

11) Sarah Bänziger, Marinus van Uden and Jacques Janssen, "Praying and Coping: the Relation between Varieties of Praying and Religious Coping Styles," Mental Health, Religion and Culture 11, no. 1 (2008): 101-118. 
attitudes, beliefs, experiences, and knowledge."12 Het is dus niet verwonderlijk dat er wereldwijd veel variaties in bidvormen en bidgedrag bestaan. ${ }^{13}$ Volgens de psycholoog James is de essentie van bidden een vorm van innerlijke verbinding of gesprek met een als goddelijk beschouwde macht. ${ }^{14}$ Ook Tremlin ziet bidden als een vorm van communicatie die gelijkenis vertoont met de intermenselijke communicatie. ${ }^{15}$ Veel bidders schrijven zowel menselijke als bijzondere eigenschappen aan deze macht toe.

Hoe werkt bidden indien het als manier wordt ingezet om problemen en emoties beter te kunnen hanteren, dus als een vorm van religieuze coping ${ }^{16}$ Uit het onderzoek van Pargament et al. komen de volgende psychologische functies van religieuze coping naar voren, die ook kunnen gelden voor bidgedrag. ${ }^{17}$ Ten eerste draagt religieuze coping bij aan het verminderen van spanningen doordat religieuze oriëntaties helpen om een betekenis te vinden achter moeilijke omstandigheden (to find meaning). ${ }^{18}$ Bidden is in hoge mate verbonden met religieuze zingeving. Volgens Paloutzian \& Park activeren bidders religieuze betekenissystemen (meaning systems) waaraan zij energie en motivatie ontlenen. ${ }^{19}$ Doordat bidden zoveel positieve betekenis voor hen heeft, voelen bidders zich vaak na het bidden beter dan daarvoor. Als zij bijvoorbeeld menen dat bidden weer perspectief biedt, zijn zij na het bidden vaak ook meer ontspannen en gerustgesteld. ${ }^{20}$ Ten tweede helpt religieuze coping om invloed uit te oefenen op het eigen bestaan (mastery and control). ${ }^{21}$ Religieuze oriëntaties en het verrichten van religieuze handelingen, zoals bidden, geven in moeilijke tijden houvast. Bidden kan gezien worden als een handeling die mensen inzetten om hun greep op ingrijpende omstandigheden te vergroten en wel via het inroepen van de hulp van God. Zo kunnen zij zich ‘hernemen'. Door te bidden versterken zij hun gevoel van controle, waardoor gevoelens van machteloosheid, wanhoop en ontreddering kunnen afnemen. Ten derde versterkt religieuze coping gevoelens van emotionele geborgenheid bij God (comfort and closeness to God). ${ }^{22}$ Door een betrokken en liefdevolle God in het gebed als nabij te ervaren en om steun te vragen, roepen gelovigen positieve gevoelens op, waardoor zij kracht

12) Spilka and Ladd, The Psychology of Prayer, 3.

13) Bänziger, Still Praying Strong.

14) “... every kind of inward communion or conversation with the power recognized as divine”. William James, The Varieties of Religious Experience. A Study in Human Nature (New York: Random House, The Modern Library, 1902/1958), 454.

15) Todd Tremlin, Minds and Gods. The Cognitive Foundations of Religion (Oxford: University Press, 2006).

16) Pargament, The Psychology of Religion and Coping.

17) Pargament et al., "The Many Methods of Religious Coping”.

18) Ibid.

19) R.F. Paloutzian and C.L. Park, "Directions for the Future of the Psychology of Religion and Spirituality: Research Advances in Methodology and Meaning Systems," in Handbook of the Psychology of Religion and Spirituality second edition, R.F. Paloutzian and C.L. Park (New York: The Guilford Press, 2015), 651-667.

20) Levine, "Prayer as Coping"; Spilka and Ladd, The Psychology of Prayer.

21) Pargament et al., "The Many Methods of Religious Coping”.

22) Ibid. 
en vertrouwen hervinden. Veel gelovigen vinden dit in tijden van nood en emotionele ontreddering troostend. Veel mensen bidden op moeilijke momenten, als zij overspoeld worden door emoties of even niet weten wat zij moeten doen. Dan zoeken zij steun, houvast en emotionele geborgenheid bij de goddelijke kracht die zij als invloedrijk, betrokken, aandachtgevend en liefdevol ervaren. ${ }^{23}$ Bij deze hen gunstig gezinde (benevolent) 'Ander' kunnen zij hun frustraties, verdriet en angsten uiten, en om vergeving vragen. Dit kan een dusdanig geruststellend effect op hen hebben, dat hun angsten en spanningen afnemen en gevoelens van ontreddering en wanhoop minder worden. ${ }^{24} \mathrm{Er}$ is weer ruimte voor hoop en vertrouwen in de toekomst. Hierdoor kunnen bidders zich na hun gebed beter voelen dan daarvoor. Ten vierde schept religieuze coping een band met geloofsgenoten en God (intimacy with others and closeness to God). ${ }^{25}$ Zo ervaren gelovige bidders dat zij er niet alleen voor staan en dat andere mensen in hun leven ook met ongeluk, verlies en problemen te maken krijgen, want zoals men wel zegt: gedeelde smart is halve smart. Ook kunnen zij steun vinden door samen met geloofsgenoten te bidden of vinden zij het troostend als anderen voor hun welzijn bidden. Ook het bidden voor anderen heeft een heilzame werking. Ten vijfde biedt religieuze coping de mogelijkheid om het eigen leven ingrijpend te veranderen (life transformation) door dit vanuit religieuze idealen vorm te geven. ${ }^{26}$ Dit kan innerlijke groei en zelfwaardering vergroten. Een gebed kan iemand stimuleren om standvastig naar innerlijke religieuze verandering te streven. Ten zesde kan bidden bijdragen aan het versterken van de sociale identiteit. ${ }^{27}$ Als men in staat is om volgens idealen te leven, door bijvoorbeeld een gebedsplicht goed na te leven, bevordert dit volgens Levine het gevoel dat men een goed mens is. ${ }^{28}$ Op deze wijze kan bidden bijdragen aan zelfwaardering. Bidden versterkt het besef verbonden te zijn met andere geloofsgenoten die vanuit hun religieuze identiteit, zowel in het verleden als het heden, met behulp van hun gebed tegenslagen hebben overwonnen. Door te bidden in moeilijke tijden en de hoop niet te verliezen, voelt men zich een waardig lid van de religieuze gemeenschap waarmee men zich identificeert. Ten zevende kan religieuze coping bijdragen aan het verminderen van stress omdat het geloofsverdieping kan versterken. ${ }^{29}$ Door te bidden kan men religieuze ervaringen oproepen, waardoor wereldse problemen als minder urgent en relevant worden beleefd.

\footnotetext{
23) Pargament, The Psychology of Religion and Coping.

24) Michael E. McCullough, Giacomo Bono and Lindsey M. Root, "Religion and Forgiveness," in Handbook of the Psychology of Religion and Spirituality, 394-411; K. Ladd and D. N. McIntosh, "Meaning, God, and Prayer: Physical and Metaphysical Aspects of Social Support," Mental Health, Religion and Culture 11, no. 1 (2008): 2338; Levine, "Prayer as Coping".
}

25) Pargament et al., "The Many Methods of Religious Coping”.

26) Ibid.

27) Kenneth I. Pargament, Margaret Feuille and Donna Burdzy, "The Brief RCOPE: Current Psychometric Status of a Short Measure of Religious Coping," Religions 2, no. 1 (2001): 51-76.

28) Levine, "Prayer as Coping".

29) Pargament et al., "The Brief RCOPE”. 
Tot slot kan er ook een achtste functie van religieuze coping en van bidden worden onderscheiden, namelijk lichamelijke ontspanning. ${ }^{30}$ Degene die bidt kan fysiologische veranderingen bij zichzelf bewerkstellingen, waardoor er een ander bewustzijn en een andere emotionele toestand ontstaan. ${ }^{31}$ Bidden kan zo functioneren als middel voor stressontlading, als een geconditioneerde stimulus, waarmee geoefende bidders zichzelf tot rust weten te brengen. Als het lichaam tot rust komt, verminderen de fysiologische reacties op stress, waardoor ook angst- en stressreacties afnemen en het gevoel van welbevinden kan toenemen. ${ }^{32}$ Levine brengt dit in verband met een meditatieve, contemplatieve wijze van bidden. ${ }^{33}$ lemand kan dan tijdens het gebed 'in stilte' verkeren. Hij geeft ook het voorbeeld van het Joodse gebed, dat door de fysieke effecten van het zingen, de aanwezigheid van rituele symbolen, de signalen tijdens de dienst en het oproepen van religieuze concepten een ander bewustzijn creëert. ${ }^{34}$ De vaste structuur in het bidden van de Islam kan ook bijdragen aan lichamelijke ontspanning.

Pargament beschouwt religieuze coping, waaronder bidden, indien het bovengenoemde gunstige effecten op iemands welzijn heeft, als een vorm van positieve religieuze coping. ${ }^{35} \mathrm{Hij}$ onderscheidt echter ook vormen van religieuze coping die juist spanningen oproepen (religious distress). Gedachten over zonden, goddelijke straf, de hel en de angst verdoemd te zijn, kunnen gaan domineren. Er kan innerlijke onvrede ontstaan als goddelijke steun uitblijft, er religieuze vervreemding optreedt, of als men zich door God verlaten voelt (God alienation). Er kunnen spanningen en conflicten met geloofsgenoten zijn rondom de interpretaties van religieuze onderwerpen. Daardoor kunnen gevoelens van minderwaardigheid, eenzaamheid en wanhoop toenemen. Er kunnen ook nadelige lichamelijke effecten door bidgedrag ontstaan. Zo kunnen bidders die te veel nadruk leggen op het op juiste wijze uitvoeren van bidrituelen, ook fysiologische klachten en spanningen bij zichzelf veroorzaken, doordat men te weinig rekening houdt met de eigen fysieke beperkingen en men over de eigen grenzen heen gaat.

30) K.S. Masters and G.I. Spielmans, "Prayer and Health: Review, Meta-Analysis and Research Agenda," Journal of Behavioural Medicine 30 (2007): 329-338.

31) Levine, "Prayer as Coping".

32) Michael J. Breslin and Cristopher A. Lewis, "Theoretical Models of the Nature of Prayer and Health: a Review," Mental Health, Religion and Culture 11, no. 1 (2008): 9-12.

33) Levine, "Prayer as Coping".

34) Ibid.

35) Pargament, The Psychology of Religion and Coping. 


\section{Bidden van moslims}

\subsection{Islamitische traditie}

Hoe mensen precies bidden wordt ook bepaald door de religieuze traditie waartoe zij behoren. Wat is er bekend over het bidden van moslims en in hoeverre gebruiken zij bidden als vorm van religieuze coping?

Gelovige moslims hechten veel waarde aan het op dagelijkse basis verrichten van hun gebedsplicht, het bidden van de salaat. Dit gebed maakt onderdeel uit van een van de vijf zuilen van de islam. Moslims zijn daarnaast ook gericht op het praktiseren van andere richtlijnen voor goed gedrag, die God hen in de koran heeft gegeven. Zij geloven in de koran, het heilige boek dat zij beschouwen als het woord van God, zoals dit aan de profeet Mohammed geopenbaard werd in de periode tussen 610 en $632 .{ }^{36}$ Zij proberen de weg van God te volgen en weerstand te bieden aan wereldse verleidingen, die zij toeschrijven aan de duivel die met hun gedachten speelt. Zij houden rekening met Gods geboden, verboden en voorschriften. Verboden zijn bijvoorbeeld moord, overspel, diefstal, het eten van varkensvlees, het drinken van bloed, het gebruik van alcoholische dranken, bedrog, gokken en onkuis gedrag. ${ }^{37}$ Daarnaast wordt ook de levenswijze van de profeet als voorbeeld gesteld, zoals die is weergegeven in de hadith en de soenna. Het vertonen van waardig gedrag wordt belangrijk gevonden, zoals het vertonen van kuis en respectvol gedrag en het respecteren van de eigen ouders. Gelovige moslims proberen te voorkomen dat zij kwaad spreken, anderen benadelen, slecht behandelen of over hen oordelen. ${ }^{38}$

\subsection{Islamitische gebeden}

De goddelijke macht die moslims in hun gebed aanspreken is Allah, het Arabische woord voor God. ${ }^{39}$ Het eren van God door te bidden, speelt een belangrijke rol in het dagelijks leven van een moslim. Het zich onderwerpen aan God, Allah, vormt de eerste zuil van de islam. Voor moslims staat de overgave en onderwerping aan God centraal. Het woord 'islam' betekent overgave. ${ }^{40}$ Het woord 'moslim' verwijst naar degene die zich heeft onderworpen. ${ }^{41}$ De aanbidding van God in het salaatgebed vormt de tweede zuil van de islam. In dit gebed geeft de gelovige zich over aan God. Vijf keer per dag bidden

36) Abdelilah Ljamai, Inleiding tot de studie van de Koran. Ontstaansgeschiedenis en methodes van de koranexegese (Zoetermeer: Meinema, 2005).

37) Seyyed H. Nasr, The Heart of Islam. Enduring Values for Humanity (New York: HarperCollins, 2004).

38) A. van Bommel, S. Rutten, P. Kruiniger, H. Ahmad Ali, B. Ahmad Ali en R. Ramsaram (ed.), Islam en de rechten van vrouwen. Deel 1. Handboek voor de empowerment van moslimvrouwen (Utrecht: Forum, 2005).

39) Veel moslims betreden een aantal keren per dag in hun salaatgebed de sacrale wereld van God. Vaak bidden zij ook buiten deze rituele gebedsvorm.

40) Nasr, The Heart of Islam.

41) D. Winchester, "Embodying the Faith: Religious Practice and the Making of a Muslim Moral Habitus," Social Forces 8, no.4 (2008): 1753-1780. 
veel moslims wereldwijd op vijf vastgestelde dagelijkse tijdstippen dit verplichte rituele gebed. De betekenis van dit gebed zullen wij nog nader toelichten. De derde zuil van de islam betreft het vasten (sawm) tijdens de maand Ramadan en de vierde zuil verplicht moslims tot het geven van aalmoezen (zakat). De laatste zuil betreft het verrichten van de bedevaart (hadj) naar Mekka.

Van alle islamitische rituelen is het bidden van het verplichte salaatgebed de belangrijkste gebedsvorm. ${ }^{42}$ Volgens Ljamai zijn islamitische geleerden van mening dat er alleen van een gebed sprake is als er verzen uit de koran worden gereciteerd. ${ }^{43}$ De recitatie van diverse koranverzen (tilawa) staat centraal in de wijze waarom moslims God eren. Het woord 'koran' verwijst naar recitatie, het voorlezen. De koran bevat soera's, die opgedeeld zijn in verzen. Bij aanvang van en tijdens het salaatgebed wordt de openingssoera uit de koran, het al-fatiha, gereciteerd. In dit korte aanvangsgebed wordt God zowel aanbeden als om bijstand gevraagd. Het bidden van de salaat versterkt bij veel moslims het besef dat voor hen God en het eeuwige leven in het hiernamaals essentieel zijn. Door dit verplichte gebed met overgave te bidden, verkeert een moslim in de aanwezigheid van God en vervult hij of zij een belangrijke religieuze plicht, waardoor religieuze verdienste (hasanat) en de kans op het paradijs toeneemt. Het volbrengen van hun religieuze gebedsplicht geeft hen innerlijke rust en voldoening. Kenmerkend voor het salaatgebed is volgens Heiler dat dit gebed in hoge mate is geritualiseerd. ${ }^{44}$ Dit geldt zowel voor hoe dit gebed wordt voorbereid, de tijdstippen waarop wordt gebeden, de gebedsrichting, de gebedshoudingen, de gebedsgebaren, als voor de woordkeuze. ${ }^{45}$ Voorafgaand aan dit rituele gebed dient men zich eerst ritueel te reinigen, door het uitvoeren van de woedoe en het uitspreken van de juiste intentie (niyyah). Het salaatgebed kan overal worden verricht, mits er een plek is om te bidden die als schoon wordt beschouwd. ${ }^{46}$ Volgens Heiler fungeert het 'plichtgebed', de salaat, als geschenk of offer aan God. ${ }^{47}$ Door het verrichten van dit rituele gebed toont een moslim aan God zijn of haar overgave, toewijding en respect. Hoewel er in het salaatgebed nauwelijks ruimte is om zich in de eigen taal, in eigen woorden of op een eigen manier uit te drukken, kunnen volgens Heiler vrome bidders het met aandacht reciteren als een krachtig middel ervaren om nader tot God te komen. Ook de respondenten uit het onderzoek van Winchester noemen het bidden van de salaat "Gods time". ${ }^{48}$ Het bidden van de salaat wordt door moslims geassocieerd met het vinden van innerlijke rust op basis van de koran, waar het woord 'bidden' vaak verbonden wordt met het vinden van vrede en rust. ${ }^{49}$ Dit

\footnotetext{
42) Nasr, The Heart of Islam.

43) Ljamai, Inleiding tot de studie van de Koran.

44) Friedrich Heiler, Das Gebet. Eine religionsgeschichtliche und religionspsychologische Untersuchung, 3e druk (München: Verlag von Ernst Reinhart, 1921).

45) Ibid.

46) John L. Esposito, The Oxford Dictionary of Islam (Oxford: Oxford University Press, 2003).

47) Heiler, Das Gebet.

48) Winchester, "Embodying the Faith".

49) M.H. Shakir, Concordance of the Qur'an. Extracted from the M.H. Shakir Translation of the Qur'an (New York: Tahrike Tarsile Qur'an Inc., 2005).
} 
wordt in verband gebracht met zich overgeven aan Gods wil en het besef dat alleen het eeuwige leven van belang is. Winchester beschouwt de salaat als een vorm van bewegende meditatie, vanwege de ontspannende effecten van dit gebed. Volgens Winchester kan de salaat bij praktiserende moslims naast dankbaarheid ook "humility" en "mindfulness" versterken. Voor gelovige praktiserende moslims geeft het vijf keer op een dag bidden van de salaat structuur en orde aan hun bestaan. Door het salaatritueel ontstaan op een dag vijf sacrale momenten warop moslims de serene, vredige wereld van God kunnen betreden. ${ }^{50}$

Een ander belangrijk gebed dat moslims uitvoeren, is het smeekgebed of douagebed. In dit gebed vragen zij God persoonlijk om steun. Douagebeden kunnen gecombineerd worden met het salaatgebed, maar zij kunnen ook op allerlei andere momenten worden uitgesproken. ${ }^{51}$ Bij deze gebeden kan er sprake zijn van zowel vaste, gestandaardiseerde gebedsformules in het klassiek Arabisch, alsook van een verzoek aan God in de eigen taal en met eigen woorden. Een bidder kan in het douagebed problemen aan God voorleggen en daarbij onzekerheden, angsten, spanningen in het contact met anderen, wensen of behoeften uiten. ${ }^{52}$ Doua- of smeekgebeden zijn dus te beschouwen als vraaggebeden (petitionairy prayer). Veel moslims bidden niet alleen smeekgebeden voor hun eigen welzijn, maar vragen daarnaast ook steun van God voor het welzijn van anderen. In het dagelijks leven spreken veel moslims smeekgebeden uit om elkaar te troosten. Douagebeden versterken daardoor de verbondenheid met geloofsgenoten. Naast de salaat en het smeekgebed bidden moslims ook andere islamitische gebeden die een ontspannende en geruststellende werking kunnen hebben, zoals korte lofgebeden, de zgn. dhikrgebeden die moslims uitspreken om God te eren. ${ }^{53}$ Deze dhikrgebeden bestaan bijvoorbeeld uit het vaak herhalen van aanroepingen, zoals het uitspreken van Gods naam of Zijn 99 namen. De aard van dergelijke gebeden wordt ook wel meditatief genoemd, vanwege de wijze waarop deze gestandaardiseerde korte lofgebeden op ritmische wijze worden herhaald. 54

\subsection{Religieuze coping en bidden van moslims}

Volgens het onderzoek van Abu Raiya, Pargament, Mahoney \& Stein ${ }^{55}$ maken moslims net als andere gelovigen in tijden van nood en spanningen gebruik van religieuze coping, zoals bidden. Ook islamitische respondenten putten in tijden van nood veel kracht uit hun geloof, hun geloofsgemeenschap

50) Winchester, "Embodying the Faith".

51) Salih Yucel, The Effects of Prayer on Muslim Patients' Well-being (Boston: Boston University, School of Theology, 2007).

52) Ibid.

53) Ibid.

54) Ibid.

55) H. Abu Raiya, K.I. Pargament, A. Mahoney and C. Stein, "A Psychological Measure of Islamic

Religiousness: Development and Evidence for Reliability and Validity," International Journal for the Psychology of Religion 18, no. 4 (2008): 291-315. 
en het contact met God. ${ }^{56}$ Zij vinden in hun geloof emotionele geborgenheid, betekenis, een sterke identiteit, spiritualiteit en verbondenheid en steun vanuit hun geloofsgemeenschap. Mahmood duidt op de persoonlijke kracht die de moslima's uit haar onderzoek in een moskee in Caïro ontwikkelen met behulp van het salaatgebed. ${ }^{57}$ Deze vrouwen gebruiken het salaatgebed om innerlijke verandering te bewerkstellingen. Als zij voorafgaand aan hun salaatgebed hun angst voor de hel en hun ontzag voor God oproepen, beleven zij tijdens hun gebed het contact met hun Schepper bewuster en intenser, aldus Mahmood. Op deze wijze zou zich een zgn. vrome-zelf (pious self) ontwikkelen met als gevolg een hogere zelfwaardering. Douagebeden worden door moslims gebruikt om de hulp van God in te roepen. Zij kunnen bijgevolg een belangrijke rol spelen in het copingproces. In een smeekgebed vragen moslims om de steun van God. Van de ervaring van de nabijheid en betrokkenheid van God kan een troostende werking uitgaan. ${ }^{58}$

Psychologisch gezien kunnen de manieren waarop moslims bidden hen dus op allerlei manieren ondersteunen bij het hanteren van spanningen. Rondom het bidden van islamitische gebeden kunnen er volgens Abu Raiya \& Pargament echter ook spanningen, zoals religieuze twijfels en innerlijke strijd optreden.59 Hiervan kan sprake zijn als moslims twijfelen over het nut van bidden, het bestaan van het hiernamaals en de hel, als men zich vervreemd voelt van God, als verwachte rustgevende effecten uitblijven of als smeekbeden niet verhoord worden. Ook het praktiseren van de salaat zelf kan spanningen veroorzaken. Bijvoorbeeld als men meent dat God gebeden niet zal accepteren omdat zij met onvoldoende overgave zijn gebeden. Men kan zich schuldig naar God voelen als men de gebedsplicht verzaakt of als men dit ritueel als zinloos en leeg ervaart. Omdat de koran als Gods woord en als de ultieme waarheid wordt beschouwd, kan het uiten van twijfels of kritiek op islamitische overtuigingen en praktijken problematisch zijn. Men kan dan al snel door geloofsgenoten als afvallige of godslasteraar gezien worden.

Binnen de Nederlandse context is onder islamitische jongeren uit migrantengezinnen van Marokkaanse afkomst het bidden van de salaat als tweede zuil van de islam een belangrijk onderdeel

56) Abu Raiya and Pargament, "Religious Integrated Psychotherapy with Muslim Clients".

57) Saba Mahmood, "Rehearsed Spontaneity and the Conventionality of Ritual: Disciplines of Salat," American Ethnologist 28, no.4 (2001): 827-853; S. Mahmood, Politics of Piety. The Islamic Revival and the Feminist Subject (Princeton/Oxford: Princeton University Press, 2005).

58) Abu Raiya and Pargament, “Religious Integrated Psychotherapy with Muslim Clients”; Z.H. Khan, P.J. Watson and Z. Chen, "Differentiating Religious Coping from Islamic Identification in Patient and Non-patient Pakistani Muslims,” Mental Health, Religion \& Culture 14, no. 10 (2011): 1049-1062.

59) Abu Raiya and Pargament, "Religious Integrated Psychotherapy with Muslim Clients". 
geworden van hun islamitische identiteit. ${ }^{60}$ Het bidden van de salaat geeft hen houvast bij het vormgeven van hun leven in Nederland. Door dit gebed te praktiseren, voelen deze jongeren zich wereldwijd verbonden met geloofsgenoten. Deze religieuze identiteit beschermt tegen discriminatie op basis van hun achtergrond. Dit laatste staat mede in verband met de toenemende negatieve beeldvorming over de islam, zoals deze naar voren komt in kranten, op televisie, op internet en sociale media en in de Tweede Kamer bij de discussies over de islam. ${ }^{61}$

\section{Uitvoering van het kwantitatieve onderzoek}

Zoals in de inleiding gesteld hebben we bij het kwantitatieve onderzoeksdeel gebruik gemaakt van een vragenlijst die door 177 respondenten werd ingevuld. Het onderzoek is uitgevoerd in 2009. Bij de benadering van respondenten is er gebruik gemaakt van de sneeuwbalmethode via de netwerken van docenten en studenten van de hulpverleningsopleidingen van de Hogeschool van Amsterdam. Daarnaast zijn moslima's benaderd op diverse opleidingslocaties in Amsterdam en Utrecht. Er is voor een groep hoogopgeleide vrouwen gekozen omdat zij door hun opleiding vaak goed in staat zijn hun ervaringen en gevoelens te verwoorden. In dit deel van het onderzoek beantwoorden wij de vraag in hoeverre en hoe hoogopgeleide moslima's van Marokkaanse afkomst bidden gebruiken als vorm van religieuze coping door middel van drie kwantitatieve onderzoeksinstrumenten die bij het promotieonderzoek van Van der Valk zijn gebruikt, ${ }^{62}$ namelijk de bidfrequentie, varianten van bidden uit het onderzoek van Bänziger, Van Uden \& Janssen, ${ }^{63}$ en de Brief RCOPE-schaal van Pargament et al. ${ }^{64}$

De 'bidfrequentie' verwijst naar de mate waarin de respondenten verschillende belangrijke vormen van islamitische gebeden bidden, zoals de salaat en smeekbedes en het bidden van andere islamitische gebeden. De vragen die ten aanzien van de bidfrequentie in de vragenlijst zijn opgenomen, zijn: “Bid je de salaat”, “Bid je smeekbedes” en “Bid je tot Allah buiten de salaat en smeekbedes”. Bij de bidfrequentie van de eerste en laatste vraag zijn vier antwoorden mogelijk, namelijk: (1) ja, altijd, (2) ja, vaak, (3) ja, soms en (4) nee, nooit. Bij het bidden van smeekbedes is de eerste antwoordmogelijkheid, “ja, altijd," niet aangeboden, wel de laatste drie. Hiervoor is gekozen omdat moslims niet altijd een smeekgebed hoeven te bidden. Dus de vraag: “Bid je smeekbedes?” heeft drie antwoordmogelijkheden, namelijk: (1) ja, vaak, (2) ja, soms en (3) nee, nooit. Varianten van bidden hebben we onderzocht

60) Martijn de Koning, Zoeken naar een "zuivere" islam. Geloofsbeleving en identiteitsvorming van jonge Marokkaans-Nederlandse moslims (Amsterdam, 2008); Ineke Roex, Sjef van Stiphout en Jean Tillie, Salafisme in Nederland: aard, omvang en dreiging (Amsterdam: WODC, Universiteit van Amsterdam, Instituut voor Migratie- en Etnische Studies, 2010); M. Maliepaard en M. Gijsberts, Moslims in Nederland (Den Haag: Sociaal en Cultureel Planbureau, 2012).

61) J. Tillie, Gedeeld land. Het multiculturele ongemak van Nederland (Amsterdam: Meulenhoff, 2008).

62) Van der Valk, Steun zoeken bij Allah.

63) Bänziger et al., "Praying and Coping".

64) Pargament et al., "The Many Methods of Religious Coping”; Pargament et al., "The Brief RCOPE". 
met behulp van de gebedsvariantenschaal van Bänziger et al. ${ }^{65}$ Met deze schaal kunnen patronen van bidden worden vastgesteld. We gebruikten 23 van de 24 items, die beantwoord konden worden met (1) nooit, tot (5) altijd.

De schaal om de wijze van religieuze coping van deze moslima's vast te kunnen stellen, de Brief RCOPE-schaal, bestaat uit twee subschalen, één schaal met 7 items voor vormen van positieve religieuze coping (afgekort als PRC) en één schaal met 7 items voor vormen van negatieve religieuze coping (afgekort als NRC). Beide schalen hebben vier antwoordmogelijkheden die variëren van (1) bijna nooit, tot (4) bijna altijd. De items van de schaal voor positieve coping, de PRC verwijzen naar een: "sense of connectedness with a transcendent force, a secure relationship with a caring God, and a believe that life has a greater benevolent meaning." ${ }^{66}$ Een voorbeeld van een item is: "Als ik problemen heb, zoek ik Gods liefde en zorg." Bij de schaal voor negatieve coping, de NRC hebben de items betrekking op: "spiritual tensions and struggles with oneself, with others and the divine." 67 Het gaat daarbij om vragen over het zich gestraft of verlaten voelen door God of door geloofsgenoten, het in de ban zijn van de duivel, of religieuze twijfel. Een voorbeeld van een item is: "Als ik problemen heb, vraag ik mij af of mijn geloofsgenoten mij in de steek hebben gelaten."

Bij het vaststellen van de definitieve vragenlijst hebben wij een aantal items geherformuleerd, zodat zij geschikter zijn voor een islamitische onderzoekspopulatie. Zo is bijvoorbeeld bij alle items het woord 'God' vervangen door 'Allah', het Arabische woord voor God.

\section{Onderzoeksresultaten}

Het bidden van de hoogopgeleide respondenten van Marokkaanse afkomst is allereerst onderzocht door vragen te stellen over hoe vaak zij twee belangrijke islamitische gebedsvormen gebruiken - de salaat en de smeekbedes - en hoe vaak zij op een andere manier bidden. De 177 respondenten bidden veel, zoals blijkt uit hun antwoorden op de vragen over de bidfrequentie, weergegeven in tabel 1:

Tabel 1 Bidfrequentie van islamitische gebedsvormen in percentages

\begin{tabular}{|l|c|c|c|c|}
\hline $\mathbf{N}=177$ & Ja altijd & Ja vaak & Ja soms & Nee nooit \\
$(\mathbf{1})$ & $72)$ & $(4)$ \\
\hline 1 Bid je de salaat? & 72.3 & 15.3 & 11.3 & 1.1 \\
\hline 2 Bid je smeekbedes & n.v.t. & 47.5 & 48.0 & 4.5 \\
\hline 3 Bid je buiten de salaat en de smeekbedes tot Allah? & 22.0 & 30.5 & 40.1 & 7.3 \\
\hline
\end{tabular}

65) Bänziger et al., "Praying and Coping".

66) Pargament et al., "The Brief RCOPE”, 58.

67) Ibid., 51. 
Het bidden van het verplichte, rituele salaatgebed speelt een belangrijk rol in het leven van de meeste moslima's. Het percentage van onze respondenten dat aangeeft altijd de salaat te bidden, is hoog (72.3\%). En bijna negen van de tien vrouwen uit ons onderzoek (87.6\%) zeggen dit gebed vaak of altijd te verrichten. Slechts $11.3 \%$ zegt dit soms en $1.1 \%$ zegt dit nooit te doen. Deze vorm van bidden wordt dus veel gepraktiseerd. Maar ook andere islamitische gebeden worden veel gebruikt. Ongeveer de helft van de respondenten bidt vaak smeekbedes (47.5\%). En iets meer dan de helft van de vrouwen (52.5\%) bidt daarnaast ook vaak tot altijd andere gebeden. Sommige vrouwen (namelijk 7.3\%) bidden echter nooit op een andere wijze. Gezien de antwoorden op de vragen naar bidfrequentie van islamitische gebedsvormen bidden de meeste respondenten dus de gebedsvormen die vanuit hun religieuze traditie worden voorgeschreven.

De moslima's uit onze studie combineren verschillende soorten islamitische gebeden. Dit blijkt uit de onderlinge correlaties tussen de bidfrequenties van de salaat, de smeekbedes en andere gebeden. Daarbij is het verband tussen het frequent bidden van smeekbedes en het vaak bidden van andere gebedsvormen het sterkst $\left(r=0.39^{* * 68}\right)$, gevolgd door het verband tussen de bidfrequentie van smeekbedes met die van de salaat $(r=0.32 * *)$. De correlatie tussen het frequent bidden van de salaat met het frequent bidden van andere gebedsvormen is lager $\left(r=0.19^{*}\right)$. Deze correlaties geven aan dat een hoge frequentie van het bidden van smeekbedes - meer dan het bidden van de salaat - verwijst naar het tevens veelvuldig bidden van andere islamitische gebeden.

Vervolgens hebben we gezocht naar manieren van bidden. Dit deden we, zoals gezegd, door gebruik te maken van 23 bidvariantenitems uit het onderzoek Bänziger et al. ${ }^{69}$ Uit de statistische analyses (principale componentenanalyses) traden vier manieren van bidden naar voren. Een daarvan kreeg het label het crisisgebed. Dit gebed bestaat uit vier items met de volgende aanleidingen om te bidden: verdrietig voelen, moeilijke momenten, iets nodig hebben, confrontatie met ziekte en dood. Deze factor verwijst naar het bidden op moeilijke, crisisachtige momenten. Van deze vier items hebben wij één schaal gemaakt. De Cronbach's alpha-coëfficiënt van deze schaal is 0.74. In tabel 2 wordt deze schaal gepresenteerd met de percentages instemming geordend naar de hoogte van de factorlading per item.

68) ** verwijst naar een significantie $=0.01$ of kleiner; * betekent dat de significantie 0.05 of kleiner is.

69) Bänziger et al., "Praying and Coping". 
Tabel 2 Gebedsvariant Crisisgebed geordend naar factorlading en de frequentie per item in percentages

\begin{tabular}{|l|c|c|c|c|c|c|}
\hline $\mathbf{N}=172-176$ & $\begin{array}{c}\text { Factor } \\
\text { lading }\end{array}$ & $\begin{array}{c}\text { Nooit } \\
(1)\end{array}$ & $\begin{array}{c}\text { Zelden } \\
(2)\end{array}$ & $\begin{array}{c}\text { Af en toe } \\
(3)\end{array}$ & $\begin{array}{c}\text { Vaak } \\
(4)\end{array}$ & $\begin{array}{c}\text { Altijd } \\
(5)\end{array}$ \\
\hline 1 Ik bid als ik mij verdrietig voel & 0.78 & 6.8 & 7.4 & 31.8 & 31.3 & 22.7 \\
\hline $\begin{array}{l}2 \\
\text { Moeilijke momenten zijn voor mij } \\
\text { aanleiding om te bidden }\end{array}$ & 0.73 & 5.1 & 6.3 & 26.3 & 41.1 & 21.1 \\
\hline $3 \quad$ Ik bid als ik iets nodig heb & 0.67 & 9.8 & 14.4 & 36.2 & 25.9 & 13.8 \\
\hline $\begin{array}{l}\text { Als ik geconfronteerd word met } \\
\text { ziekte of dood ga ik bidden }\end{array}$ & 0.50 & 4.1 & 2.9 & 17.4 & 36.6 & 39.0 \\
\hline
\end{tabular}

Uit tabel 2 blijkt dat bij deze 177 islamitische respondenten het crisisgebed gemiddeld een score behaalt van 3.6, dit is tussen "af en toe" en "vaak" in. Bij drie van de vier items scoort de meerderheid van de respondenten "vaak" of "altijd". Alleen bij het item "Ik bid als ik iets nodig heb" is dit niet het geval. Wellicht komt dit omdat in dit item het instrumentele karakter van bidden al te duidelijk zichtbaar is. Uit het crisisgebed blijkt dus dat deze moslima's ook een manier van bidden gebruiken die te beschouwen is als een vorm van religieuze coping.

Het gebruik van religieuze coping onder de 177 respondenten is verder vastgesteld met behulp van de Brief RCOPE. Dit onderzoeksinstrument is ontwikkeld door Pargament et al. om vormen van positieve en negatieve religieuze coping te kunnen vaststellen. ${ }^{70}$ Op basis van antwoorden van de 177 respondenten op de items van deze religieuze copingschaal, de Brief RCOPE, komen de volgende resultaten naar voren. Deze zijn in de onderstaande tabel 3 terug te vinden. In deze tabel valt allereerst te zien dat de religieuze coping op grond van een principale componentenanalyse in tweeën uiteenvalt: positieve en negatieve religieuze coping. Bij deze principale componentenanalyse, ${ }^{71}$ laden de zeven items van de positieve religieuze copingschaal (de PRC-schaal) op één factor. Wij hebben de items van deze factor, die verwijst naar vormen van positieve religieuze coping, daarom in één schaal opgenomen. De Cronbach's alpha-coëfficiënt van deze schaal is 0.85 . De maximale score op deze schaal van zeven items is 28 en de minimale score is 7 . De gemiddelde score van de vrouwen uit ons onderzoek op deze schaal is 22.98 (3.28 per item). De standaarddeviatie is 3.96.

Uit de schaal voor positieve religieuze coping (PRC) blijkt dat ongeveer acht tot negen van de tien vrouwen bij problemen regelmatig zoeken naar (dit wil zeggen op basis van zowel de antwoordcategorie “bijna altijd” als “vaak”) Allah's liefde en zorg (91.3\%). Zij streven naar een sterkere band met Allah (89.3\%), vragen vergeving van zonden (87.5\%) en pakken met hulp van Allah hun problemen aan (84.6\%). Zij zoeken Gods hulp om beter om te kunnen gaan met boosheid (81.5\%). Zij proberen tegen-

\section{0) Pargament et al., "The Brief RCOPE".}

71) Principale componentenanalyse met varimax rotatie, missing pairwise, $\mathrm{n}$ factors $=2$, factorlading: 0.40 , verklaarde variantie: $28.9 \%+19.9 \%=48.8 \%$. 
slag te zien als iets waardoor Allah hen sterker maakt (79.3\%) en concentreren zich op hun geloof om te stoppen met piekeren (77.8\%). De items van de negatieve religieuze copingschaal (de NRC-schaal) laden niet alle zeven op één factor, een factor die verwijst naar negatieve vormen van religieuze coping. Twee items laden niet op deze factor. Het item: "Stel ik vragen bij de macht van Allah" laadt op de factor positieve religieuze coping. Dit item is dus niet als een vorm van negatieve religieuze coping te beschouwen. En een ander item: "Concludeer ik dat het door toedoen van de duivel is gebeurd" heeft een te lage factorlading. Deze twee items zijn vervolgens niet in de schaal voor negatieve religieuze coping opgenomen. De schaal voor negatieve religieuze coping (NRC), bestaat dus uit vijf items. De Cronbach's alpha-coëfficiënt van deze schaal is 0.76. De scoremogelijkheid op deze schaal van vijf items varieert van 5 (laag) tot 20 (hoog). De gemiddelde score op de schaal is 7.86 (1.57 per item). De standaarddeviatie is 2.68. Bij de negatieve religieuze copingschaal, de NRC-schaal, blijkt dat twee op de tien respondenten aangeeft dat zij problemen regelmatig als straf van Allah beschouwen door hun gebrek aan toewijding (20.9\%). Hierbij wordt het probleem dus aan zichzelf toegeschreven (interne attributie). De andere items worden duidelijk minder onderschreven. lets meer dan één op de tien vraagt zich bij problemen regelmatig af waarom Allah hen straft (13\%).

Tabel 3 Brief RCOPE schaalitems met de subschalen PRC en NRC, geordend naar de percentages per item van de antwoordcategorie "bijna altijd"

\begin{tabular}{|c|c|c|c|c|}
\hline $\begin{array}{l}\text { PRC: positieve vormen van religieuze coping } \\
N=172-177\end{array}$ & $\begin{array}{c}\text { Bijna } \\
\text { nooit } \\
\text { (1) }\end{array}$ & $\begin{array}{c}\text { Soms } \\
\text { (2) }\end{array}$ & $\begin{array}{c}\text { Vaak } \\
\text { (3) }\end{array}$ & $\begin{array}{c}\text { Bijna } \\
\text { altijd } \\
(4)\end{array}$ \\
\hline $\begin{array}{l}1 \text { Als ik problemen heb vraag ik om vergeving voor mijn } \\
\text { zonden }\end{array}$ & 2.3 & 10.2 & 26.7 & 60.8 \\
\hline 2 Als ik problemen heb zoek ik Allah's liefde en zorg & 2.3 & 6.4 & $34 \cdot 3$ & 57.0 \\
\hline $\begin{array}{l}3 \text { Als ik problemen heb streef ik naar een sterkere band met } \\
\text { Allah }\end{array}$ & 2.3 & 8.5 & 35.6 & 53.7 \\
\hline $\begin{array}{l}4 \text { Als ik problemen heb, zoek ik hulp bij Allah om mij niet te } \\
\text { laten leiden door boosheid }\end{array}$ & 5.8 & 12.7 & 35.8 & 45.7 \\
\hline $\begin{array}{l}5 \text { Als ik problemen heb probeer ik met hulp van Allah het } \\
\text { probleem aan te pakken }\end{array}$ & 1.7 & 13.6 & 42.0 & 42.6 \\
\hline $\begin{array}{l}6 \text { Als ik problemen heb probeer ik te zien hoe Allah mij er } \\
\text { sterker door probeert te maken }\end{array}$ & 4.6 & 16.1 & 40.8 & 38.5 \\
\hline $\begin{array}{l}7 \text { Als ik problemen heb concentreer ik me op mijn geloof, } \\
\text { zodat ik kan stoppen met piekeren }\end{array}$ & 4.5 & 17.6 & 42.0 & 35.8 \\
\hline
\end{tabular}




\begin{tabular}{|l|c|c|c|c|}
\hline $\begin{array}{l}\text { NRC: negatieve vormen van religieuze coping } \\
\text { N }=172-177\end{array}$ & $\begin{array}{c}\text { Bijna } \\
\text { nooit } \\
\text { (1) }\end{array}$ & Soms & Vaak & $\begin{array}{c}\text { Bijna } \\
\text { altijd } \\
\text { (3) }\end{array}$ \\
\hline Als ik problemen heb stel ik vragen bij de macht van Allah & 32.6 & 24.4 & 26.2 & 16.9 \\
\hline $\begin{array}{l}\text { Als ik problemen heb concludeer ik dat dit door toedoen van } \\
\text { de duivel is gebeurd }\end{array}$ & 27.4 & 42.9 & 19.4 & 10.3 \\
\hline $\begin{array}{l}\text { 1. Als ik problemen heb vraag ik mij af of Allah nog wel van } \\
\text { mij houdt }\end{array}$ & 62.7 & 27.7 & 4.5 & 5.1 \\
\hline $\begin{array}{l}\text { 2. Als ik problemen heb voel ik mij gestraft door Allah voor } \\
\text { mijn gebrek aan toewijding }\end{array}$ & 33.9 & 45.2 & 15.8 & 5.1 \\
\hline $\begin{array}{l}\text { 3. Als ik problemen heb vraag ik mij af of mijn } \\
\text { geloofsgenoten mij in de steek hebben gelaten }\end{array}$ & 68.4 & 23.7 & 4.0 & 4.0 \\
\hline $\begin{array}{l}\text { 4. Als ik problemen heb vraag ik mij af wat ik heb gedaan dat } \\
\text { Allah mij straft }\end{array}$ & 44.6 & 42.4 & 9.6 & 3.4 \\
\hline $\begin{array}{l}\text { 5. Als ik problemen heb vraag ik me af of Allah mij misschien } \\
\text { verlaten heeft }\end{array}$ & 76.6 & 18.9 & 2.3 & 2.3 \\
\hline
\end{tabular}

Uit de correlaties tussen de bidfrequentie en de schalen voor het meten van religieuze coping blijkt dat het bidden van zowel smeekbedes $\left(r=0.39^{* *}\right)$ als het bidden van de salaat $\left(r=0.38^{* *}\right)$, meer dan andere vormen van bidden $\left(r=0.25^{* *}\right)$ in positieve zin verband houden met vormen van positieve religieuze coping. Dit geeft aan dat bidden voor een deel aansluit bij positieve religieuze coping. $\mathrm{Er}$ bestonden geen significante correlaties tussen bidfrequenties en negatieve religieuze coping.

De 177 Nederlandse hoogopgeleide islamitische vrouwen van Marokkaanse afkomst bidden op moeilijke momenten en bij problemen veelvuldig verschillende rituele gebedsvormen die binnen de islam gebruikelijk zijn. Het crisisgebed werd regelmatig gebeden en positieve religieuze coping scoorde hoog. De overgrote meerderheid van deze moslima's zoekt bij problemen in gebed de liefde en zorg van God. Tijdens het bidden kunnen zij hun hart luchten en verkrijgen zij kracht en steun. Zij vragen om vergeving, streven naar een sterkere band met God, zoeken Zijn hulp om zich niet door boosheid te laten leiden, pakken met hulp van God hun problemen aan, zien hoe God hen door problemen sterker probeert te maken en concentreren zich op hun geloof om te stoppen met piekeren. Door in hun gebed God om steun te vragen, vertrouwen zij op een goede afloop van de moeilijke situaties waarmee zij worden geconfronteerd. Zij gebruiken dus bij problemen over het algemeen vooral positieve vormen van religieuze coping. Negatieve vormen van religieuze coping komen nauwelijks voor.

\section{Conclusie en discussie}

De conclusie uit ons onderzoek is dat bidden relevant is bij het copingproces van Nederlandse hoogopgeleide moslima's van Marokkaanse afkomst. Uit het kwantitatieve onderzoek onder 177 responden- 
ten blijkt dat de overgrote meerderheid van deze jonge vrouwen veel bidt, met name het salaatgebed, maar ook smeekbedes en andere vormen van gebed. Het crisisgebed is een algemeen voorkomende manier van bidden. Daarnaast is de score op de positieve religieuze copingschaal hoog. Zij benaderen hun stress door zich in gebed tot God te richten en om vergeving en steun te vragen. Er bestaan positieve correlaties tussen de bidfrequentie en de schaal voor het meten van positieve religieuze coping. Naarmate moslima's meer bidden hanteren ze ook meer positieve vormen van religieuze coping, die volgens de literatuur samenhangen met positieve welzijnseffecten. ${ }^{72}$ Deze onderzoeksresultaten sluiten grotendeels aan bij de theorievorming over religieuze coping en bidden van Pargament, Koenig \& Perez..$^{73}$ Bidden op moeilijke, stressvolle momenten kan helpen om: (1) to find meaning, (2) mastery and control, (3) comfort and closeness to God, (4) intimacy with others and closeness to God, (5) life transformation. Dit geldt ook voor de functies die Pargament, Feuille \& Burdzy hier later nog aan toevoegen, namelijk de functie ten aanzien van identiteit (identity) en het zoeken van het heilige of spiritualiteit op zich (the search for the sacred or spirituality itself). ${ }^{74}$ Maar een belangrijk aspect van het bidden van deze moslima's is ook de heilzame ontspannende werking die volgens hen van bidden uitgaat. Dit sluit aan bij de theorievorming over bidden van Masters \& Spielmans en Levine. ${ }^{75}$ De wijze waarop moslims bidden, bevordert lichamelijke en geestelijke ontspanning.

Het is mogelijk dat sommige items in de vragenlijst niet duidelijk genoeg waren voor deze islamitische respondenten. Een item van de Brief RCOPE-schaal voor het meten van negatieve religieuze coping "Stel ik vragen bij de macht van Allah" bleek een onderdeel van de schaal voor positieve religieuze coping. De reden dat dit item niet binnen de schaal voor negatieve religieuze coping valt, heeft mogelijk te maken met een verkeerde vertaling. Het item "Questioned the power of God" had waarschijnlijk beter vertaald kunnen worden als “Twijfel ik aan de macht van Allah". Ook zijn onder deze 177 islamitische respondenten weinig negatieve vormen van religieuze coping vastgesteld, zoals twijfel over religieuze opvattingen, of negatieve religieuze gevoelens ten aanzien van God of de islam. Dit komt overeen met het onderzoek van Abu Raiya \& Pargament. ${ }^{76}$ Deze onderzoekers brengen dit in verband met het belang dat moslims hechten aan de overgave aan God, Zijn wil, het lot en de waarheid van Gods openbaring in de koran. Moslims worden daardoor aangemoedigd om altijd op God te vertrouwen. Een kritische houding ten opzichte van het religieuze referentiekader wordt afgekeurd. Als men twijfelt aan Gods bedoelingen, religieuze opvattingen of het nut van religieuze rituelen die door God worden voorgeschreven, is men immers niet loyaal aan God en getuigt men niet

\footnotetext{
72) Pargament et al., "The Brief RCOPE”.

73) Pargament et al., "The Many Methods of Religious Coping”.

74) Pargament et al., "The Brief RCOPE”, 52, 53.

75) Masters and Spielmans, "Prayer and Health"; Levine, "Prayer as Coping".

76) Abu Raiya and Pargament, "Religious Integrated Psychotherapy with Muslim Clients”.
} 
meer van vertrouwen en overgave. Dit kan als godslastering ervaren worden en cognitieve dissonantie oproepen.

Dat de moslima's uit deze studie bidden gebruiken voor het verminderen van hun spanningen, wil nog niet zeggen dat bidden volstaat. Bidden kan iemand helpen om minder impulsief vanuit emoties op een situatie te reageren. Dit kan strategisch gezien voordelen hebben. Sommige problemen vragen echter ook om structurele oplossingen waarbij het gericht oplossen van problemen adequater is. Als het om ingewikkelde problemen en ingrijpende gebeurtenissen gaat, is er meer nodig dan bidden alleen om emoties te kunnen hanteren. De raad en steun van anderen kan onontbeerlijk zijn om ingrijpende gebeurtenissen te verwerken of om ingewikkelde keuzes te kunnen maken. Verschillende respondenten geven dit ook aan. Daarnaast kan bidden vermijdingsgedrag versterken, indien problemen dusdanig worden gerelativeerd of gebagatelliseerd, dat belangrijke conflicten onopgelost blijven.

De vraag die naar aanleiding van ons onderzoek ook gesteld moet worden, is in hoeverre ons onderzoek vooral sociaal wenselijke antwoorden heeft opgeleverd en of bidden in werkelijkheid inderdaad wel zo stress verminderend werkt. Het kan immers zo zijn dat zij God niet willen afvallen of niet durven te vertellen over hun teleurstellingen over het effect van bidden. Dit strookt immers niet met hun zelfbeeld als moslima. Gebedsrituelen kunnen daarnaast ook routinematig worden uitgevoerd en verstoken blijven van een innerlijke beleving. In het kwalitatieve onderzoek geven bijvoorbeeld verschillende moslima's aan dat zij zich tijdens het bidritueel van de salaat niet goed op de recitaties van gebeden kunnen concentreren, omdat zij worden afgeleid door gedachten aan problemen en dagelijkse beslommeringen. Ook is het niet duidelijk in hoeverre zij tijdens het bidden iets als Gods aanwezigheid ervaren. Toch geeft ons onderzoek voldoende aanwijzingen dat de meeste van deze moslima's zich tijdens hun gebed verbonden voelen met een vertrouwensvolle en barmhartige God. Tot slot kan de vraag gesteld worden in hoeverre deze groep van 177 respondenten ten aanzien van hun religiositeit en coping representatief is voor andere Nederlandse moslima's van Marokkaanse afkomst. Voor de beantwoording van deze vraag is meer onderzoek nodig onder een bredere groep moslima's.

Dr. Leonie N.H. van der Valk is cultureel antropoloog en werkzaam bij de Hogeschool van Amsterdam.

E-mail:I.n.h.van.der.valk@hva.nl

Prof. dr. Jos Z.T. Pieper is godsdienstpsycholoog en verbonden aan de Universiteit van Tilburg. E-mail: jos.pieper@ziggo.nl

Prof. dr. Marinus H.F. van Uden is klinisch psycholoog en verbonden aan de Universiteit van Tilburg. E-mail:m.vuden@home.nl 